\title{
Prefeeding Plasma Acetoacetate and Glucose in Healthy, Lactating Heifers. Variations Related to Milk Yield, Metabolic Balances and Stage of Lactation
}

\author{
By K. Halse $e^{1}$ and B. Tveit ${ }^{2}$ \\ ${ }^{1}$ Department of Biochemistry, Physiology and Nutrition, Norwegian College of Veterinary Medicine, Oslo, and \\ the ${ }^{2}$ Department of Animal Science, Agricultural University of Norway, Ås-NLH, Norway.
}

\begin{abstract}
Halse. K. and B. Tveit: Prefeeding plasma acetoacetate and glucose in healthy, lactating heifers. Variations related to milk yield, metabolic balances and stage of lactation. Acta vet. scand. 1994, 35, 243-255. - When measured before morning feeding plasma acetoacetate (ACAC) increased and glucose (GL) decreased significantly with increasing milk yield (fat corrected, $\mathrm{FCM}$ ) within 2 groups of half-sister related heifers which did not suffer from clinical ketosis. The groups received respectively A: $7 \mathrm{~kg}$ and B: 4 $\mathrm{kg} / \mathrm{d}$ of concentrates in addition to grass silage ad libitum (each group 88 animals). Correlation coefficients of the same magnitude between the 3 variables mentioned were obtained in the 1st and 3rd month of lactation in spite of a narrowing of the ACAC range from $0.024-0.66$ to $0.019-0.16 \mathrm{mmol} / \mathrm{l}$. Reproducibility of differences between animals in milk yield and in the plasma components was evidenced by significant correlations between measurements in the 1st and 3rd month. The B-animals produced $2.4 \mathrm{~kg} / \mathrm{d}$ less FCM than the better fed A group (A, 1st month of lactation 19.8 $\pm 3.1 \mathrm{~kg} / \mathrm{d}$ ) while the mean values for ACAC and GL remained practically unaffected by the difference in feeding. B cows gave consistently $5-6 \%$ lower GL means $(p<0.01)$ than $\mathrm{A}$ animals with identical yields.

Animals which showed marked ACAC increment during the first 5-6 weeks of lactation produced $3-4 \mathrm{~kg}$ more $\mathrm{FCM} / \mathrm{d}$ than equally fed animals with constantly low ACAC levels. The estimated energy deficit of this ketonaemic, high-producing category corresponded to the production of $4.5-6 \mathrm{~kg} \mathrm{FCM} / \mathrm{d}$ from body reserves. Low ACAC values $(<0.05 \mathrm{mmol} / \mathrm{l})$ were reproduced with a standard deviation of $\pm 4 \%$ with the automated nitroprusside method described.
\end{abstract}

cows; primiparous; early lactation; non-ketotic; constant concentrate rations; underfeeding; correlations; milk yield; ketone maxima; post-parturient timing.

\section{Introduction}

Cows receiving their food rations in 2 meals per day, with limited access to food during the night, show marked diurnal variations in blood metabolite levels (Radloff et al. 1966, Hove \& Blom 1973, Blum et al. 1985, Sutton et al. 1988, Borrebak et al. 1990, Cisse et al. 1991). During the first hours after a meal it is typical for blood ketones to increase and blood sugar to decrease. Minima in ketone bodies and maxima in glucose observed when the animals are hungry before morning feeding, coincide with diurnal maxima in the level of non-esterified fatty acids (NEFA). Bowden (1971) considered the time of day of sampling to be important in attempts to use blood NEFA and ketone bodies as indicators of the nutritional status of ruminants. 
There are good reasons to believe that blood metabolite levels measured before morning feeding are particularly informative. The metabolic effects of variations in the wholeday energy balance must be easier to detect in the morning when digestion in the rumen is at a diurnal minimum, than during peak hours of absorption of fermentation products after a meal. Hove's (1974) studies of prefeeding insulin-glucose interrelations provided early evidence of the advantage of eliminating meal effects as sources of variation. Positive correlations between the 2 parameters observed before a meal can be obscured by inversely related variations after feeding (Hove \& Blom 1973. Borrebaek et al. 1990). When sampled before morning feeding at stages of lactation when they are not susceptible to clinical ketosis, most cows have plasma acetoacetate levels below $0.05-0.06 \mathrm{mmol} / \mathrm{l}$, giving mean and $\mathrm{SD}$ $0.025 \pm 0.01 \mathrm{mmol} / 1$ (Halse et al. 1983 a. Ropstad et al. 1989). The mentioned figures define a minimum range for prefeeding acetoacetate which can be used as a reference in studies of factors affecting the ketone metabolism during lactation. The metabolic significance of moderate variations in prefeeding acetoacetate is shown by the fact that small increments to levels above the mimimum range $(>0.05$ $\mathrm{mmol} / \mathrm{l}$ ) are associated with detectable changes in the means for other parameters: decreases in plasma glucose (Halse et al. 1983 a), increments in plasma NEFA (Dale et al. 1979) and in the contents of long-chain fatty acids in milk fat (Halse et al. 1983 b), decreases in plasma corticosteroids (Blom \& Halse 1975) and in plasma thyroxine (Ropstad et al. 1989). Similarly, small decreases in prefeeding plasma glucose within a normal range were found to be accompanied by significant decreases in insulin (Hove 1974). In the present article an attempt is made to provide further information concerning the signifi- cance of prefeeding acetoacetate and glucose as metabolic indicators in normal animals by studying relations to milk yield in healthy heifers.

\section{Materials and methods}

Observations are pooled from 3 identically designed experiments with about 60 individually fed heifers per year in 1981/82, 83/84 and 85/86 at the Department of Animal Science, the Agricultural University of Norway. Identically planned feeding experiments were performed with the same number of animals each year for 8 years (1978-86). During this long period as many as $6 \%$ of the animals were treated for ketosis. In a previous article (Malmstrøm et al. 1987) it was shown that large year-to-year variations in the incidence of the disease could be explained by differences in the quality of the grass silage used. In 3 of the years no cases of clinical ketosis were recorded, and findings from these years are discussed separately in the present article.

\section{Animals}

Animals were of the Norwegian Red breed, selected in about equal numbers as daughters of the same 20 sires each year. They calved while indoor-fed in the period from the second half of August to early in December at about 2 years of age.

\section{Feeding}

Two half-sister related feeding groups with equal numbers of animals and approximately equally timed calving dates were established from the beginning of the indoor-feeding period. Concentrate rations were kept constant irrespective of milk yields, the "normal « $\mathrm{A}$ group receiving respectively 6 and $7 \mathrm{~kg}$ per day in the first and following 3 months of lactation, while the »low « B group consistently received $3 \mathrm{~kg} / \mathrm{d}$ less. The rations were in- 
creased gradually from 1 to $5 \mathrm{~kg} / \mathrm{d}$ in group A and from 1 to $3 \mathrm{~kg}$ in group $\mathrm{B}$ during the last 4 weeks before parturition. Both groups received $1 \mathrm{~kg}$ of hay/d. Grass silage preserved with formic acid was provided ad libitum. Offered and unconsumed amounts were weighed for each individual 4 days per week. The average consumption of silage dry matter in the 4th week of lactation was about $7.5 \mathrm{~kg} / \mathrm{d}$ in the A group and $8.5 \mathrm{~kg} / \mathrm{d}$ in the low-concentrate B group both in 1981/82 and 1985/86. For unknown reasons figures as low as A: 6.3 and B: $7.0 \mathrm{~kg} / \mathrm{d}$ were obtained in 83/84. From the 4th to the 12th week post partum silage consumption either decreased moderately (by 5 $10 \%$ ) or remained practically constant (in 83/84). Appetite differences between individuals were indicated by standard deviations of the silage dry matter intake amounting to about $\pm 1 \mathrm{~kg} / \mathrm{d}$.

The animals were fed and milked at $6 \mathrm{a} . \mathrm{m}$. and at about 3 p.m. By assuming medium quality of the ingested feeds it was found that the animals received feed units in excess of requirements for maintenance and body growth of heifers corresponding to A: 17 and 18.3 and $\mathrm{B}$ : 12.7 and $14 \mathrm{~kg} \mathrm{FCM} / \mathrm{d}$, respectively, in the 4th and 12 th week of lactation.

\section{Yield}

Milk yields (kg/d) and milk fat (\%) were determined once per week.

\section{Blood plasma}

Blood plasma was produced by centrifugation of fresh blood drawn with heparinized vacutainers from the jugular vein before feeding in the morning. To preserve acetoacetate the plasma were stored in plastic tubes in liquid nitrogen or in a deep-freezer at $-80^{\circ} \mathrm{C}$.

Plasma samples were taken weekly during the first 8 weeks of lactation and, thereafter, at more irregular intervals.

\section{Analyses}

As in previous studies (Blom \& Halse 1975. Borrebak et al. 1990) automated photometric methods (Autoanalyser II) were used for the determination of plasma glucose, ferricyanide reduction in phosphate buffer at $\mathrm{pH} 12$, and of acetoacetate by the nitroprusside colour reaction in $2 \mathrm{~mol} / \mathrm{l}$ ethanolamine at $\mathrm{pH} 10$.

The automated acetoacetate method described by Klein \& Oklander (1966) was modified by the introduction of dialysis technique. In this way errors due to accidental traces of hemoglobin were eliminated. Without dialysis barely visible concentrations of hemoglobin in plasma could cause $100 \%$ errors at low levels of acetoacetate. The sensivity of the colour reaction was increased by the use of ethanolamine buffer and by ice-cooling of the reaction mixture. The photometric noise level was reduced by using a three-point system for the injection of nitroprusside solution into the reagent stream from the dialyzer. Reanalysis of plasma after storage for a couple of days at $80^{\circ} \mathrm{C}$ gave a standard deviation of \pm 4.2 per cent when acetoacetate was as low as $<0.05$ $\mathrm{mmol} / \mathrm{l}$. After prolonged storage: (6-12 months) recoveries at 2 acetoacetate levels were: $101.6 \pm 4.3 \%(0.06 \mathrm{mmol} / \mathrm{l}, \mathrm{n}=32)$ and $99.1 \pm 6.1 \%$ ( $0.22 \mathrm{mmol} / \mathrm{l}, \mathrm{n}=73)$. In comparison the decay of acetoacetate in plasma at $0-5^{\circ} \mathrm{C}$ was found to be about $4 \%$ per day. Acetoacetate standards, $0.03-2.0 \mathrm{mmol} / \mathrm{l}$, were prepared from $10 \mathrm{mmol} / \mathrm{l}$ stock solutions (ethyl acetoacetate hydrolyzed with $\mathrm{NaOH}$ ) kept at $-80^{\circ} \mathrm{C}$. Practically constant absorptivity values were obtained within the range from $<0.1$ to $1.5-2 \mathrm{mmol} / \mathrm{l}$. Analytical values with nitroprusside were about $5 \%$ above the enzymatically determined level (Williamson \& Mellanby 1974) in the range $0.4-1.7$ $\mathrm{mmol} / \mathrm{l}$. Larger discrepancies at lower acetoacetate levels appeared due to inaccuracies of the enzymatic method (inaccurate meas- 
Table 1. Fat corrected milk yields (FCM, kg/day), acetoacetate (ACAC) and glucose (GL) in blood plasma $(\mathrm{mmol} / \mathrm{l})$. Means \pm standard deviations. Subscripts 1 or 3 denote month of lactation.

\begin{tabular}{lccc}
\hline Parameter & Group A & $\begin{array}{c}\text { Group B } \\
\mathrm{n}_{1}=88 \\
\mathrm{n}_{3}=87\end{array}$ & $\begin{array}{c}\text { Group } \\
\text { difference } \\
\text { t-test }\end{array}$ \\
\hline $\mathrm{FCM}_{1}=88$ & $19.77 \pm 3.09$ & $17.33 \pm 2.88$ & $<0.001$ \\
$\mathrm{FCM}_{3}$ & $19.03 \pm 2.51$ & $16.67 \pm 2.30$ & $<0.001$ \\
\hline ACAC $_{1}$ & $0.072 \pm 0.068$ & $0.085 \pm 0.104$ & not sign. \\
Range & $(0.024-0.440)$ & $(0.024-0.660)$ & \\
ACAC3 & $0.036 \pm 0.018$ & $0.034 \pm 0.018$ & not sign. \\
range & $(0.019-0.082)$ & $(0.019-0.160)$ & \\
\hline GL1 & $4.23 \pm 0.28$ & $4.12 \pm 0.23$ & $<0.01$ \\
GL3 & $4.33 \pm 0.23$ & $4.23 \pm 0.24$ & $<0.01$ \\
\hline
\end{tabular}

Differences between 1st and 3rd month, acetoacetate: $\mathrm{P}<0.001$, glucose: $\mathrm{P}<0.01$, t-test.

urements of small decreases in NADH). Otherwise, the specificity of the nitroprusside method was indicated indirectly by a correlation coefficient as high as $\mathrm{r}=+0.89$ to enzymatically measured 3-OH-butyrate (Borrebak et al. 1990), the quotient between the 2 ketone bodies increasing from 1:10 to about 1:4 when acetoacetate was elevated from $<0.05$ to 1.4 $\mathrm{mmol} / \mathrm{l}$.

Statistical evaluations were carried out according to Fisher (1970).

\section{Results}

First and 3rd month plasma values discussed statistically in Table 1-3, were estimated at by calculating individual means for observations from, respectively, the 2 nd to 5 th week and 7 th to 13 th week post partum.

Table 1 shows that nearly identical acetoacetate means were obtained in the A and B groups in spite of different feeding levels apparently leading to a yield difference of $2.4 \mathrm{~kg}$ FCM/d. With the large number of animals, a very moderate lowering of the glucose mean in the B group was statistically significant.

Metabolic stabilization from the 1st to the 3rd month was indicated by narrowing of ranges and decreasing averages for acetoacetate. Simultaneous small, but significant increments in glucose could be due to an antiketogenic improvement in the availability of carbohydrates in the 3 rd month. The accompanying decrease in FCM $(0.6-0.7 \mathrm{~kg} / \mathrm{d})$ was much smaller than the FCM group difference.

Table 2. Plasma acetoacetate, standard deviation (SD) of observations in Fig. 2 related to milk yield. Obtained from pooled sums of squares and degrees of freedom from within $2 \mathrm{~kg}$ milk intervals. Number of observations in brackets.

\begin{tabular}{|c|c|c|c|c|c|c|}
\hline \multirow{3}{*}{$\begin{array}{l}\text { Fat corrected } \\
\text { milk, } \mathrm{kg} / \mathrm{d} \\
\text { Interval } \\
\text { means }\end{array}$} & \multicolumn{4}{|c|}{$\mathrm{SD}$ in $\mathrm{mmol} / 1$} & \multirow{2}{*}{\multicolumn{2}{|c|}{$\begin{array}{c}\text { Variance test, } \\
\text { A against B }\end{array}$}} \\
\hline & \multicolumn{2}{|c|}{ First month } & \multicolumn{2}{|c|}{ Third month } & & \\
\hline & $\begin{array}{c}\text { Group } \\
\text { A }\end{array}$ & $\begin{array}{c}\text { Group } \\
\text { B }\end{array}$ & $\begin{array}{c}\text { Group } \\
\text { A }\end{array}$ & $\begin{array}{c}\text { Group } \\
\text { B }\end{array}$ & $\begin{array}{c}\text { First } \\
\text { month }\end{array}$ & $\begin{array}{l}\text { Third } \\
\text { month }\end{array}$ \\
\hline 13,15 and 17 & $\begin{array}{c} \pm 0.006^{\mathrm{a}} \\
\quad(24)\end{array}$ & $\begin{array}{c} \pm 0.061^{\mathrm{a}} \\
\quad(51)\end{array}$ & $\begin{array}{c} \pm 0.004^{\mathrm{a}} \\
\quad(29)\end{array}$ & $\begin{array}{c}0.010^{\mathrm{a}} \\
(62)\end{array}$ & $<0.001$ & $<0.001$ \\
\hline 19 & $\begin{array}{c} \pm 0.021 \mathrm{~b} \\
(24)\end{array}$ & $\begin{array}{c} \pm 0.131 \mathrm{~b} \\
(19)\end{array}$ & $\begin{array}{c} \pm 0.019 \mathrm{~b} \\
(26)\end{array}$ & $\begin{array}{c} \pm 0.031 \mathrm{~b} \\
(21)\end{array}$ & $<0.001$ & $<0.05$ \\
\hline 21,23 and 26 & $\begin{array}{c} \pm 0.084 \mathrm{c} \\
\quad(40)\end{array}$ & $\begin{array}{c} \pm 0.146 \mathrm{~b} \\
(18)\end{array}$ & $\begin{array}{c} \pm 0.018 \mathrm{~b} \\
(33)\end{array}$ & $\begin{array}{c} \pm 0.017 \mathrm{~b} \\
(4)\end{array}$ & $<0.01$ & not sign \\
\hline
\end{tabular}

Statistical significance within groups indicated by different letters (variance tests, $\mathrm{p}<0.01$ or 0.001 ). 
Table 3. Correlation coefficients within feeding groups $\mathrm{A}$ and $\mathrm{B}$, within months of lactation (1 and 3$)$ and between measurements from the two months. Acetoacetate (ACAC), glucose (GL), fat corrected milk (FCM).

\begin{tabular}{lcclcc}
\hline Variables & Group A & Group B & Variables & Group A & Group B \\
\hline ACAC $_{1} / \mathrm{FCM}_{1}$ & +0.51 & +0.29 & $\mathrm{ACAC}_{1} / \mathrm{GL}_{1}$ & -0.54 & -0.60 \\
$\log \mathrm{ACAC}_{1} / \mathrm{FCM}_{1}$ & +0.66 & +0.42 & $\mathrm{ACAC}_{3} / \mathrm{GL}_{3}$ & -0.55 & -0.25 \\
$\mathrm{ACAC}_{1} / \mathrm{FCM}_{3}$ & +0.45 & +0.36 & $\mathrm{FCM}_{1} / \mathrm{FCM}_{3}$ & +0.82 & +0.79 \\
$\mathrm{ACAC}_{3} / \mathrm{FCM}_{3}$ & +0.56 & +0.34 & $\mathrm{ACAC}_{1} / \mathrm{ACAC}_{3}$ & +0.39 & +0.31 \\
$\mathrm{GL}_{1} / \mathrm{FCM}_{1}$ & -0.49 & -0.43 & $\mathrm{GL}_{1} / \mathrm{GL}_{3}$ & +0.65 & +0.58 \\
$\mathrm{GL}_{1} / \mathrm{FCM}_{3}$ & -0.43 & -0.40 & & & \\
$\mathrm{GL}_{3} / \mathrm{FCM}_{3}$ & -0.44 & -0.49 & & & \\
\hline
\end{tabular}

With 85 (A) or 86 (B) degrees of freedom,

$[\mathrm{r}]>0.35: \mathrm{p}<0.001,[\mathrm{r}]>0.28: \mathrm{p}<0.01,[\mathrm{r}]>0.21: \mathrm{p}<0.05$.

The frequency curves in Fig.1 show the numbers of observations from which metabolite means in Fig. 2 were calculated. Widely varying milk yields were approximately normally distributed. According to Fig. 2 acetoactate increased, and glucose decreased with increasing levels of FCM. These yield effects, mainly associated with FCM increments above the means in Table 1, were discernible even within the narrow actetoacetate ranges of the 3rd month. Within groups nearly iden- tical regression curves were obtained for glucose at the 2 stages of the lactation cycle (Fig. 2). An effect of low concentrate rations in the $\mathrm{B}$ group is revealed when A- and B-animals with the same yield are compared: B giving the highest acetoacetate averages in the 1st month $(\mathrm{p}=0.01)$ and the lowest glucose levels $(\mathrm{p}<0.001)$ in both months. In Table 1 these group differences are partly obscured by lower yields in $\mathrm{B}$ than in $\mathrm{A}$.

Table 2 shows that the variability of acetoace-

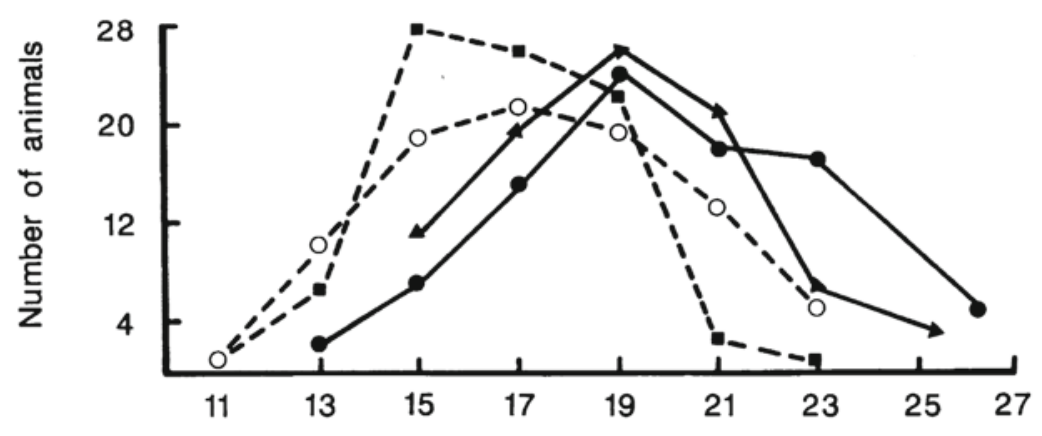

Fat corrected milk (kg/day)

Figure 1. Number of animals at different levels of milk yield (FCM). Comparison of groups and months of lactation. Mean yield in Table 1. Symbols: Full lines: Group A $\bullet$ 1st month, $\mathbf{\Delta} 3 \mathrm{rd}$ month post partum. Broken lines: Group B, O 1st month, $\mathbf{\square}$ 3rd month post partum. 


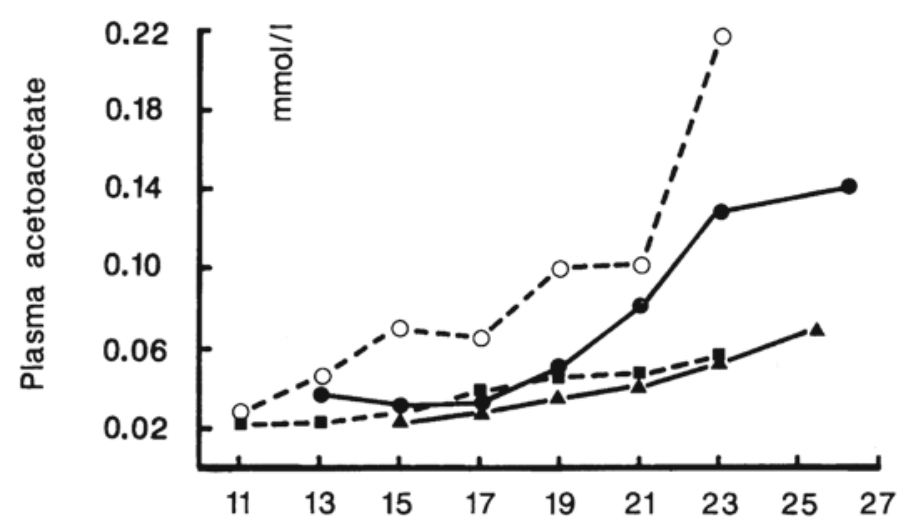

Fat corrected milk (kg/day)

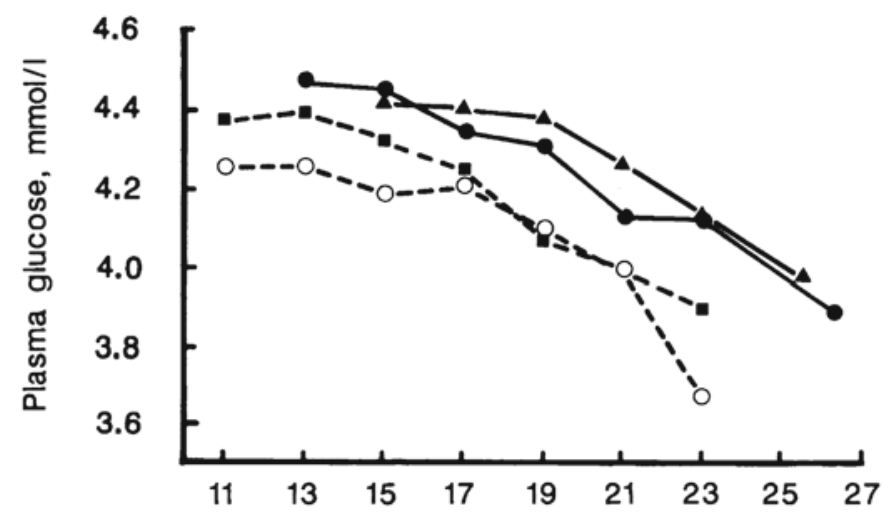

Fat corrected milk (kg/day)

Figure 2. Plasma acetoacetate and glucose averages as functions of daily FCM yield. SD of acetoacetate in Table 2. Glucose, coefficients of variation about 5 per cent. Symbols as in Fig. 1.

tate within categories of animals with equal yields increased with the yield and tended to be higher in B than in A.

The correlations indicated in Fig. 2 were statistically significant with r-values of the same magnitude in the 1st and 3rd month (Table 3). Higher correlation coefficients to FCM in both feeding groups after transformation of acetoacetate to log-scale, are consistent with the finding of non-linear regression curves for acetoacetate in Fig.2. The reproducibility of individual differences in yield is shown by correlation coefficients as high as +0.8 between FCM measurements in the 1st and 3rd month. Further, Table 3 shows that acetoacetate and glucose were significantly correlated even 

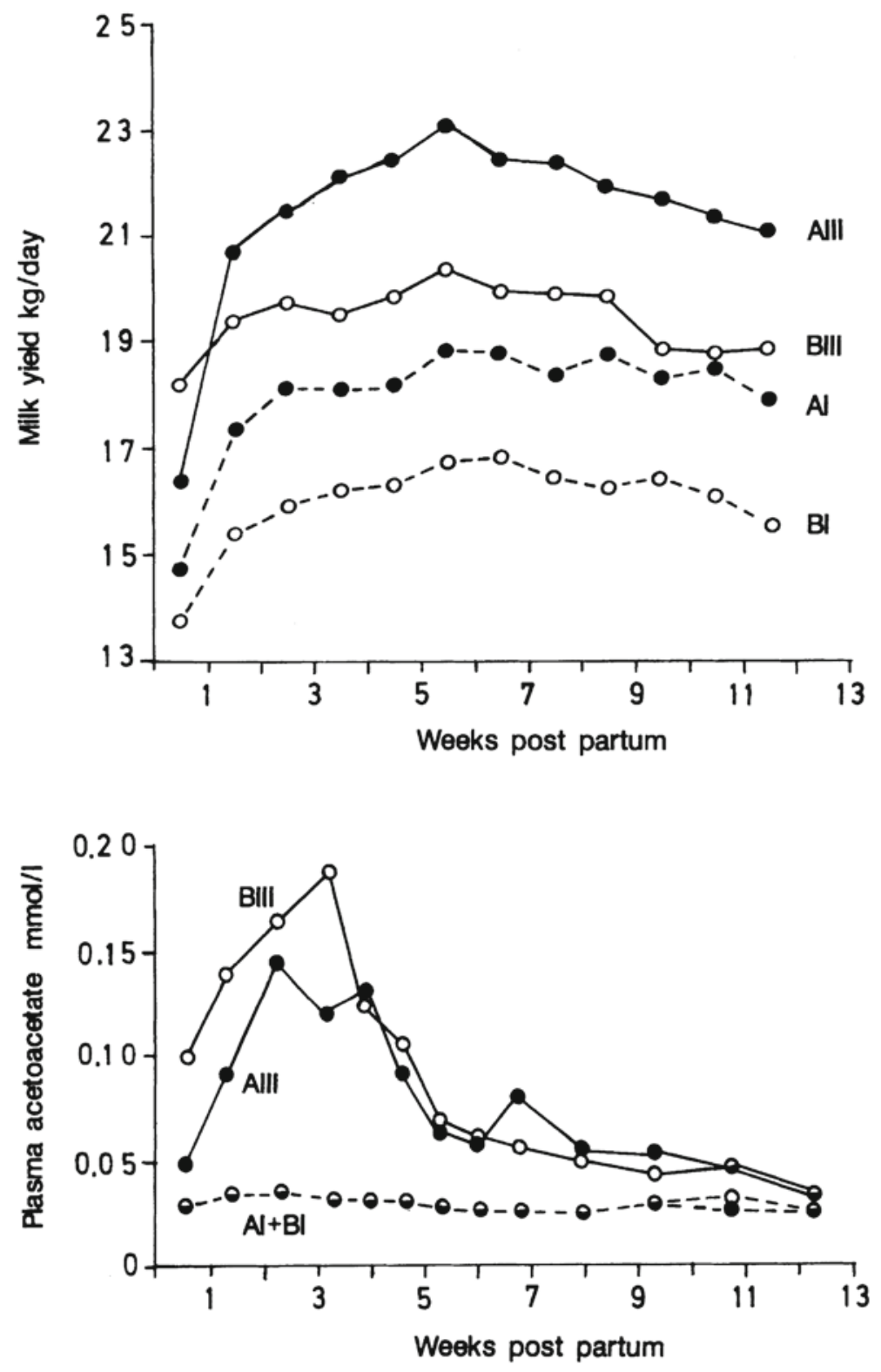

Figure 3. Plasma acetoacetate and milk yield. Variations with time post partum. Animals with constantly low acetoacetate in group A and B, A I ( $\mathrm{n}=35$------), B I ( $\mathrm{n}=31$---O---) and with marked ketone maxima, A III $(\mathrm{n}=33$ ) B III ( $\mathrm{n}=27$ O__ 


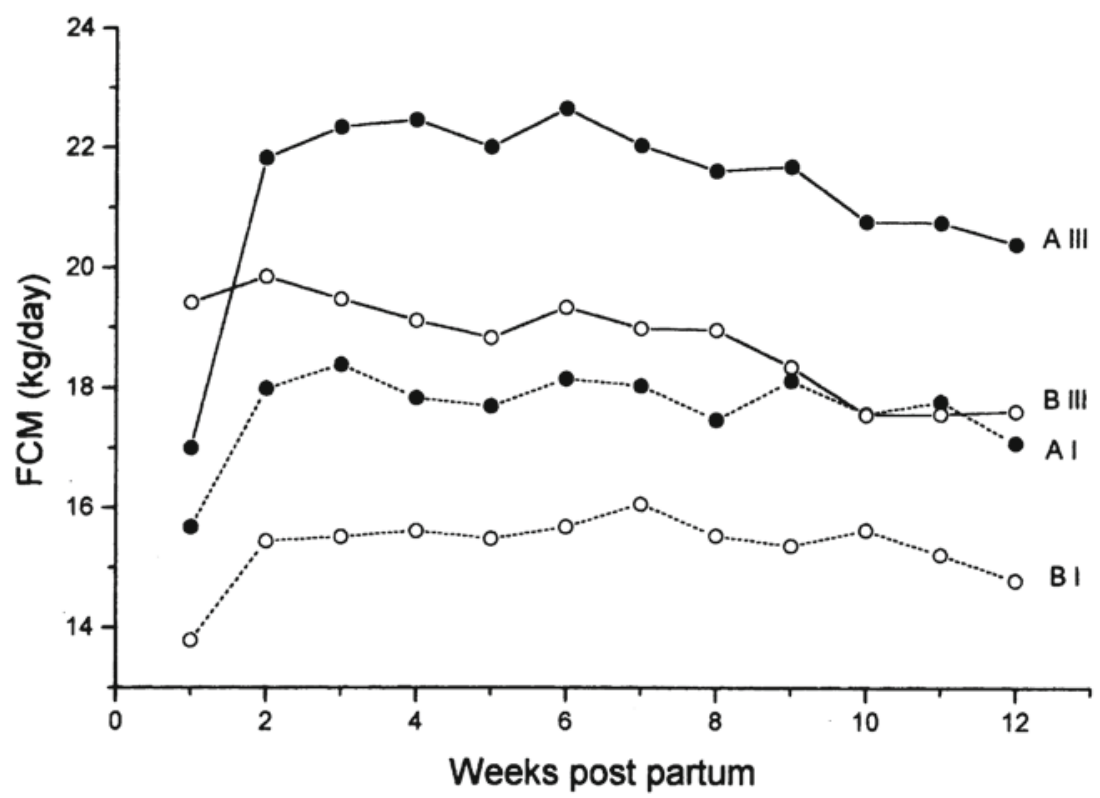

Figure 4. Fat corrected milk yields. Weekly averages of the same animals as in Fig. 3. Symbols as in Fig. 3.

within the narrow acetoacetate ranges (Table 1) of the 3rd month post partum. It should be added that even yield-independent variations in acetoacetate for which SD values are given in Table 2, were significantly correlated to glucose with $\mathrm{r}=-0.5$ and -0.25 (within groups) respectively in the 1 st and 3 rd month. The finding could not be explained by individual appetite variations: acetoacetate was not significantly correlated to voluntary silage dry matter intake (4th week of lactation, $r=-0.1$, within groups.)

According to Fig. 3 almost identical curves were obtained for time-dependent variations in acetoacetate in the two groups. Within each group about 30 animals showed acetoacetate levels below $0.05 \mathrm{mmol} / \mathrm{l}$ throughout the first 12 weeks of lactation (Category I, Fig. 3), while a similar number developed marked acetoacetate peaks within 3-4 weeks post par- tum (III). Observations from animals (II) with transient, moderate ketone increments to $0.06-0.07 \mathrm{mmol} / \mathrm{l}$ are not shown in the graph. It is remarkable that categories with ketone increments produced more milk than those with flat ketone curves, the extra yields (2-12 weeks) being II A and B: $1.3 \mathrm{~kg}$, III A: $3.8 \mathrm{~kg}$, B: $3.4 \mathrm{~kg}$ FCM/d (Fig.4).

The persistence of differences in milk yield between ketone categories during the period of declining ketone levels in Fig. 3 is consistent with the correlations between FCM in the 1 st and 3rd month of lactation in Table 3. Consistent with the correlation tests are also 0.3 $\mathrm{mmol} / \mathrm{l}$ lower glucose means in category III compared with I in both feeding groups. Animals from both groups developed ketone peaks while the uncorrected milk yield was increasing (Fig. 3). Simultaneously, the milk fat level decreased from $4.25 \%$ in the 2 nd week 


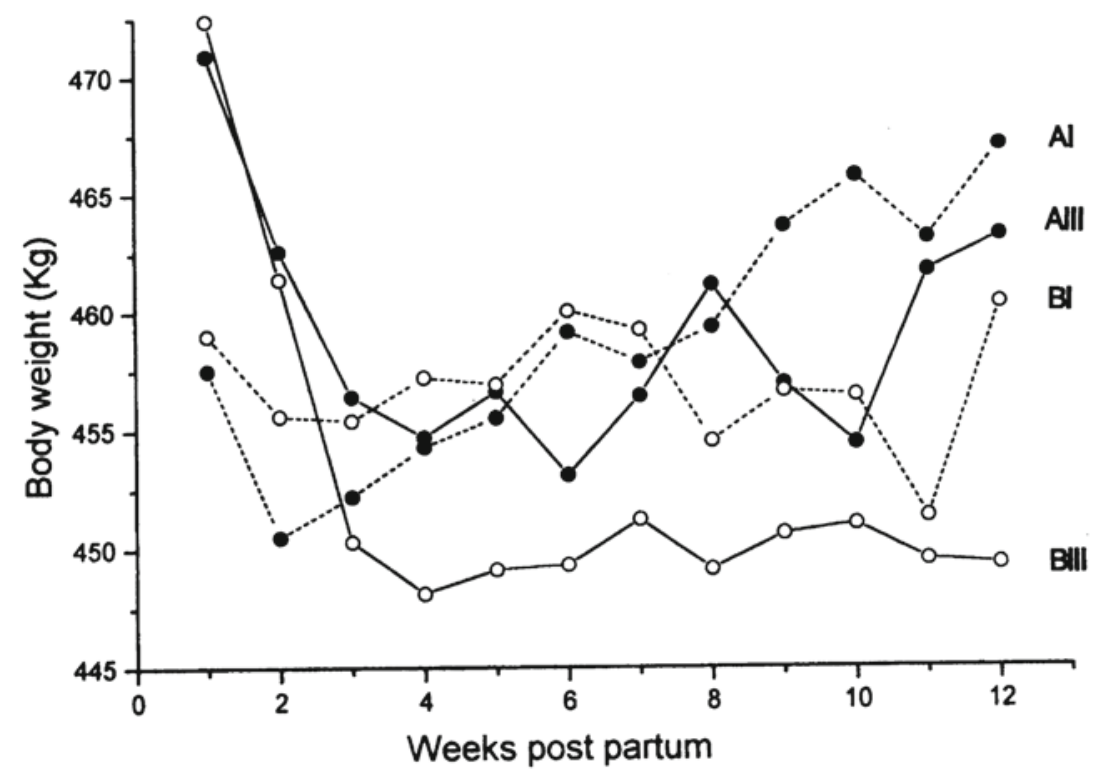

Figure 5. Post partum body weight variations. Averages corresponding to the within-group ketone categories defined in Fig. 3. Symbols as in Fig. 3.

to $3.75 \%$ in the 5 th week post partum (A and B combined). A similar decrease was seen in the animals with constantly low acetocetate levels (I). The average fat percentage was, however, somewhat higher in III than in I during this period, 4.08 versus $3.94 \%(\mathrm{p}<0.001)$, and it remained constantly higher in A than in $\mathrm{B}$ until the end of the experiment (differences $0.14-0.21 \%, \mathrm{p}<0.001$ ).

Due to decreasing milk fat concentrations the animals reached stable levels of FCM as early as 2-3 weeks post partum (Fig. 4), while the uncorrected yields were still increasing (Fig. 3). Uncorrected milk may be the best indicator of lactose production and mammary carbohydrate utilization, while energy expenditure is logically estimated in units of FCM. By comparing milk yields in Fig. 4 to calculated feeding values of the respective diets, A:17-18 $\mathrm{kg}$, B: $13-14 \mathrm{~kg} \mathrm{FCM} / \mathrm{d}$, it was found that ani- mals with ketone peaks produced about $4 \mathrm{~kg}$ (A III) and $6 \mathrm{~kg} \mathrm{FCM} / \mathrm{d}$ (BIII) from body reserves. On the other hand were $\mathrm{AI}$ and $\mathrm{BI}$ in approximate energy equilibrium. Declining yields (Fig. 4) indicate gradually improving energy balances during the period of decreasing acetoacetate (Fig. 3). It should be noted that appetite variations related to differences in acetoacetate behaviour were not detected. As expected, the greatest initial weight losses after calving occured in the animals with ketone peaks (Fig. 5). In accordance with the energy balance estimates AI gained weight continuously for 10 weeks, while the weight of the poorly-fed, high-yielding B animals remained constant after the $3 \mathrm{rd}$ week of lactation. The initial weight differences in the figure can be explained by the fact that on average category III animals were 25 days older at calving than category I (heifer growth rate $0.5 \mathrm{~kg} / \mathrm{d}$ ). 


\section{Discussion}

Inversely related prefeeding plasma acetoaceate and glucose variations within narrow ranges can reflect differences in the metabolic condition of cattle. This is best illustrated by the correlations to milk yield obtained while the acetoacetate maximum was as low as 0.082 $\mathrm{mmol} / \mathrm{l}$ (group A, Table 1 and 3 ), which is only $4 \%$ of the mean concentration in cows with clinical ketosis (Dale 1978). The significant correlations obtained between measurements in the 1st and 3rd month of lactation in Table 3 , show that moderately elevated ketone levels can indicate high capacity for milk yield.

The present findings should be compared to the demonstration by Solbu (1978) of increments in the frequency of ketosis cases in heifers in the field from 6 to above 11 per cent when the milk yield in early lactation increased from $<16$ to $>24 \mathrm{~kg} / \mathrm{d}$.

Since both clinical and subclinical ketoses (Andersson 1988) are associated with losses in milk yield, poorer correlations than in Table 3 would be predictable in field studies involving larger ketone variations than in the present material. Thus, in herds with ketosis problems Kauppinen (1983) found a correlation coefficient of +0.26 between log blood acetoacetate and approximately simultaneous milk yields. Findings are not directly comparable, however, since he took blood samples at random hours from the mammary vein and pooled observations from a wider time interval post partum than in the present study. Mammary vein blood contains more acetoacetate and less 3-OH-butyrate and glucose than jugular blood (Halse et al. 1985).

Ketone variations related to the capacity for milk production, as in the present study, were evidenced by a $5 \%$ higher annual milk yield $(\mathrm{p}<0.01)$ in cows with acetoacetate maxima $>0.36 \mathrm{mmol} / \mathrm{l}$, than in individuals with lower, »normal« maxima (Kauppinen 1984). Similar yield differences between categories of cows with different acetone maxima in the milk were reported by Andersson (1988).

As in the present study (Fig. 3) Lean et al. (1991) observed blood ketone peaks (3-OH butyrate) during the first month of lactation in individually fed cows while the energy balance was negative and the milk yield was increasing. As shown in Fig. 3, the ketone level declined in the 2 nd month in spite of continued underfeeding. At this stage Lean et al's animals were, however, gradually improving their feed consumption and nutritional balances.

Seemingly, the relationship between the degree of underfeeding and ketone metabolism is far from straightforward. The body weight curves in Fig. 5 indicate differences in the metabolic balance between groups and between categories of animals with different yields. In spite of this A- and B- animals showed practically identical metabolite means in Table 1 . This can be explained by a $2.4 \mathrm{~kg} /$ day lower milk yield and a correspondingly lower mammary utilization of glucose in $\mathrm{B}$ than in $\mathrm{A}$.

The importance of this difference appears from the fact that at equal yields the B group showed lower glucose and higher and more variable acetoacetate concentrations than group A (Fig. 2 and Table 2). The yield-related carbohydrate drain by the lactating mammary gland must be an important factor affenting the margin of glucose available for extramammary utilization and antiketogenesis. Adaptation to variations in this margin can explain respectively the negative and positive correlations of milk yield to plasma glucose and acetoacetate in Table 3.

This interpretation is supported by experiments with gluconeogenic supplements to cows (Halse \& Mфller 1978). Antiketogenic effects with doses corresponding to the 
amount of sugar in $4 \mathrm{~kg}$ milk, were obtained within acetoacetate ranges as low as in the present study. In comparison it seems likely that an extra milk yield of 3-4 kg/d can explain the difference in ketone behaviour between categories of animals in Fig. 3.

Postparturient ketone peaks timed approximately as in Fig. 3 have been observed both in the field (Mogstad \& Halse 1975. Dale et al. 1979) and in the feeding experiments of Lean et al. (1991). Ketone maxima were accompanied by minima in blood sugar. The prevalence of milk samples with a positive acetone test trebled in the course of the first 25 days post partum in an extensive material studied by Dohoo \& Martin (1984). In the following month it decreased regularly like the acetoacetate averages after the 4th week in Fig. 3. Cases of clinical ketosis are similarly timed according to Øverby et al. (1974) and Mogstad $\&$ Halse (1975). In a field practice $45 \%$ of all recorded cases ocurred between the 20th an 30th day post partum. Thereafter, the frequency decreased abruptly, and the number of cases after the 42 nd day was as low as $10 \%$ of the total (Mogstad \& Halse). Ketone maxima in early lactation in healthy cows coinciding with the maximum in susceptibility to clinical ketosis, indicate a common, physiological pattern of variations in the regulation of metabolic processes. The development of ketonaemia in Fig. 3, can be thought of as due to a lag in the metabolic adaption to increasing milk yields, leading to progressive depletion of glycogen reserves. Gradually activated gluconeogenesis could explain the subsequent recovery. Otherwise, in a discussion of bovine metabolism in early lactation it should also be taken into account that it can take several weeks post partum before cows reach maxima in digestive capacity (Liebich et al. 1987) and food consumption (Broster et al. 1978).

Milk yield was the main factor in determining metabolic balances in the present study. This fact, and the use of a standardized sampling procedure, can explain the correlations between milk yield and plasma metabolites while acetoacetate was within a narrow range. The findings do not exclude the possibility that high milk yields per se, at a given level of energy balance, can contribute to the lability of ketone metabolism. In the literature normal in comparison to subclinical ketone ranges may be arbitrarily defined (Kauppinen 1984). From a physiological point of view large variations in ketogenesis and ketone levels can be regarded as normal adaptations, favouring the energy homeostasis of animals. Therefore, the yield-related increments in acetoacetate above a physiologically defined minimum range $(<0.05 \mathrm{mmol} / \mathrm{l})$ discussed in the present article should not be looked upon as »deviatons from normal «. It is believed that the findings which have been discussed can contribute to the understanding of clinical ketosis. It is likely that further information of interest in relation to the ketosis problem can be obtained by studying the ways in which metabolic processes are integrated in healthy, lactating cows.

\section{References}

Andersson L: Subclinical ketosis in dairy cows. Vet. Clin. North Amer. Food Anim. Pract. 1988, 4, 233-51.

Blom AK, Halse $K$ : Corticosteroids in nocturnal blood plasma of cows in the field related to stage of lactation and plasma acetoacetate. Acta Endocr. (Kbh.) 1975, 78, 306-315.

Blum JW, Jans F, Moses W, Fröhli D, Zemp M, Wanner $M$, Hart IC, Thun $R$, Keller $U$ : Twentyfourhour pattern of blood hormone and metabolite concentrations in high-yielding dairy cows: Effects of feeding low or high amounts of starch, or crystalline fat. Zbl.Vet.Med.A, 1985, 32, 401-418.

Borrebak B, Halse K, Tveit B, Dale HK, Ceh L: Plasma glucose, ketone bodies, insulin, glucagon and enteroglucagon in cows. Diurnal variations related to ketone levels before feeding and to the 
ketogenic effects of feeds. Acta vet. scand. 1990, $31,5-15$.

Bowden DM: Non-esterified fatty acids and ketone bodies in blood as indicators of nutritional status in ruminants. A review. Can. J. Anim. Sci. 1971, $51,1-13$.

Broster WH, Sutton LD, Bines JA: Concentrat: forage ratios for high-yielding dairy cows. In Haresign W, Lewis D, (eds.): Recent advances in animal nutrition. Butterworths, London 1978 p. 99-128.

Cisse M, Chilliard Y, Coxam M, Davicco J, Remo B: Slow release somatotropin in dairy heifers and cows fed two levels of energy concentrate. 2. Plasma hormones and metabolites. J. Dairy Sci. 1991, 74, 1382-1394.

Dale $H$ : Ei vurdering av kliniske symptom og diagnostiske problem ved ketose (Clinical symtoms and diagnostic problems in bovine ketosis). In Thesis: Feltgranskingar over ketose hjå mjølkekyr (Field studies of ketosis in lactating cows). Norwegian College of Veterinary Medicine. 1978, 19 pages.

Dale H, Vik-Mo L, Fjellheim P: A field survey of fat mobilization and liver function of dairy cows during early lactation. Relationship to energy balance, appetite and ketosis. Nord.Vet.Med. 1979, 31, 97-105.

Dohoo IR, Martin SW: Subclinical ketosis: Prevalence and associations with production and disease. Can.J.Comp.Med. 1984, 48, 1-5.

Fisher RA: Statistical Methods for Research Workers. 14th ed. Oliver and Boyd, Edinburgh 1970.

Halse K, Møller OM: Propylenglykol til kyr med varierende grader av ketonemi. Virkninger på acetoacetat og glukose i blodplasma. Sammenligning med propionat. (Propyleneglycol to cows with varying degrees of ketonaemia. Effects on acetoacetate and glucose in blood plasma. Comparison to propionate). Norsk Vet.Tidsskr. 1978, 90, 93-99.

Halse $K$, Hove $K$, Ertsaas P: A biological definition of ketonemia in cows. Proc. 5th Internat. Conference on Production Disease in Farm Animals, Uppsala, Sweden 1983a, p. 137-140.

Halse K, Standal N, Syrstad O: Fatty acid composition of milk fat related to the concentrations of acetoacetate and glucose in blood plasma of cows. Acta agric. scand. 1983b, 33, 361-368.

Halse K, Borrebak B, Dahle HK: Jurstoffskifte og ketose hos kyr (Mammary metabolism and ketosis in cows). Norsk Vet.Tidsskr. 1985, 97, 651-654.
Hove $K$ : Nocturnal plasma insulin levels in cows with varying levels of plasma ketone bodies; relations to plasma sugar and acetoacetate. Acta Endocr. (Kbh.) 1974, 76, 513-524.

Hove K, Blom AK: Plasma insulin and growth hormone in dairy cows; diurnal variation and relation to food intake and plasma sugar and acetoacetate levels. Acta Endocr. ( Kbh.)1973, 73, 289-303.

Kauppinen $K$ : Correlations of whole blood concentrations of acetoacetate, B-hydroxybutyrate, glucose and milk yield in dairy cows as studied under field conditions. Acta vet. scand. 1983, 24, 337-348.

Kauppinen K: Annual milk yield and reproductive performance of ketotic and non-ketotic dairy cows. Zbl. Vet. Med. A, 1984, 31, 694-704.

Klein B, Oklander M: The automated determination of acetoacetate in serum and urine. Clin. Chem. 1966, 12, 606-612.

Lean IJ, Troutt HF, Bruss ML, Farver TB, Baldwin, $R L$, Galland, JC, Kratzer D, Holmberg CA, Weaver LD: Postparturient metabolic and production responses in cows previously exposed to long-term treatment with somatotropin. J.Dairy Sci. 1991, 74, 3429-3445.

Liebich H-G, Dirksen G, Arbel A, Dori S, Maier E: Fütterungsabhangige Veränderungen der Pansenschleimhaut von Hochleistungskühen im Zeitraum von der Trockenstellung bis acht Wochen post partum. (Feeding-induced changes in the rumen epithelium of high-yielding cows during the dry period and the first eight weeks post partum). J. Vet. Med. (A) 1987, 34, 661-672.

Malmstrøm P, Halse K, Tveit B, Skipenes $P$, Svendsen $M$ : Miljømessige og genetiske årsaker til klinisk og subklinisk ketose. (Environmental and genetic explanation factors for clinical and subclinical ketosis). Norsk Vet.Tidsskr. 1987, 99, 95-102.

Mogstad O, Halse K: Klinisk og sublinisk ketose hos kyr. - Tid etter kalving. (Clinical and subclinical ketosis in cows. - Time post partum.) Norsk Vet.Tidsskr. 1975, 87, 97-105.

Radloff HD, Schultz LH, Hoekstra WG: Relationship of plasma free fatty acids to other blood components in ruminants under various physiological conditions. J. Dairy Sci. 1966, 49, 179-182.

Ropstad E, Halse K, Refsdal AO: Thyroxine in blood plasma related to plasma levels of acetoacetate and glucose in ketotic and healthy cows. Acta vet. scand. 1989, 30, 175-183. 
Solbu $H$ : Forhold som virker inn på forskjellige sykdommer hos kviger. (Conditions affecting various disease conditions in heifers.) Buskap og avdrått 1978, 30, 176-179.

Sutton JD, Hart IC, Morant SV, Schuller ES, Simmonds $A D$ : Feeding frequency for lactating cows: diurnal patterns of hormones and metabolites in peripheral blood in relation to milk-fat concentration. Br.J.Nutr. 1988, 60, 265-274.

Williamson DH, Mellanby J: D-(-)-3-Hydroxybutyrate. In: Methods of Enzymatic Analysis, vol. 4. Ed. Bergmayer HU, Academic Press, New York 1974, p. 1836-1839.

$\emptyset$ verby I, Aas Hansen $M$, Jonsgård K, Søgnen E: Bovine ketosis - I. Occurrence and incidence in herds affected by ketosis in Eastern Norway 1967-1968. Nord. Vet. Med. (1974), 26, 353-361.

\begin{abstract}
Sammendrag
Plasma acetoacetat og glucose før morgenfôring hos sunne, lakterende kviger. Variasjoner relatert til melkeytelse, stoffskiftebalanse og laktasjonsstadium.
\end{abstract}

Plasma acetoacetat (ACAC) og glucose (GL) målt før morgenfôring var innbyrdes negativt korrelert og henholdsvis positivt og negativt korrelert til FCM innen to grupper av individuelt fôrede, ketosefrie, 1. gangs kalvende kyr ( 3 fors $\emptyset$ ksår, i alt 88 dyr i hver gruppe). Innen grupper ble det gitt henholdsvis A: 7 $\mathrm{kg}$ og B: 4 kg kraftfôr per dag i tillegg til grassurfôr etter appetitt. Korrelasjonene var signifikante både $i$ 1. og 3. laktasjonsmåned på tross av at $\mathrm{ACAC}$ nivåene ble halvert i mellomtiden.

Innen grupper var det signifikante korrelasjoner mellom målinger av samme variable i 1 og 3 . laktasjonsmåned. Lavere melkeytelse $(2.4 \mathrm{~kg}$ mindre) i B enn i A kan forklare at de to gruppene gav nesten identiske middelverdier for ACAC og GL. Ved lik ytelse gav B-kyr 5-6\% lavere GL enn A-kyr. Kyr med markerte ACAC maksima i de første 5-6 laktasjonsuker produserte 3-4 kg mer FCM/dag enn likt forede individer med jevnt lave ACAC, og de var i et beregnet energiunderskudd svarende til 4.5 $6 \mathrm{~kg} \mathrm{FCM} /$ dag. ACAC kulminerte i den periode post partum hvor kyr er mest utsatt for klinisk ketose.

(Received June 4, 1993; accepted May 2, 1994).

Reprints may be requested from: Karl Halse, Norwegian College of Veterinary Medicine, Box 8146 Dep., N-0033 Oslo, Norway. 
